\title{
The Role of Religiosity, Ethnicity and Gender Identification in Individual's Moral Judgments; The Mediation Effect of Self- transcendence
}

\author{
Jing Huey Chin ${ }^{1}$, Shaheen Mansori ${ }^{2 *}$, Zabihollah Rezaee ${ }^{3}$ and Saeid Homayoun ${ }^{4}$ \\ ${ }^{1}$ Faculty of Business, Malaysia University of Science and Technology, 47810 Petaling Jaya, Selangor, Malaysia \\ ${ }^{2}$ Faculty of Business, UNITAR International University, 47301 Petaling Jaya, Selangor, Malaysia \\ ${ }^{3}$ School of Accountancy, University of Memphis, Memphis, Tennessee 38152, USA \\ ${ }^{4}$ Faculty of Education and Business Studies, University of Gävle, 80176 Gävle, Sweden
}

\begin{abstract}
Most recently, corporate financial scandals, and unethical behaviour cast doubt on investors and raised public concern globally. It is due to the weak corporate governance structure and low ethic awareness amongst the people. The purpose of this research is therefore to justify the factors that influence an individual's moral judgement. This study also seeks to provide practical recommendations to corporations and different associations. As such, to evaluate the proposed hypotheses, 300 self-administered questionnaires were distributed in five universities in Malaysia using a non-probability sampling approach. As a result, the findings demonstrate that ethnicity has the highest impact on self-transcendence and moral judgement, followed by religiosity and gender identification (gender difference). The contribution of this research is to evaluate the relationships between religiosity, ethnicity, and gender identification towards moral judgement with the intervention of mediating variable (self-transcendence). In essence, ethical values and moral obligations should be highlighted in corporations, and these values should be practised and embraced into the organisational culture. Thus, organisational decisionmakers should highly emphasise the role

ARTICLE INFO

Article history:

Received: 11 July 2021

Accepted: 04 October 2021 of ethicality and morality in corporations because ethical competence aligns with an employee's responsibility as a whole.
\end{abstract}

Published: 13 December 2021

DOI: https://doi.org/10.47836/pjssh.29.4.39

$\overline{\text { E-mail addresses: }}$

victoria.chin44@gmail.com (Jing Huey Chin)

shaheen.mansori@gmail.com (Shaheen Mansori)

zrezaee@memphis.edu (Zabihollah Rezaee)

sadhon@hig.se (Saeid Homayoun)

* Corresponding author 


\section{INTRODUCTION}

Ideally, it is presumed that every firm follows corporate governance measures and practices globally. However, recent financial reports revealed the financial scandals and failure of attaining companies' objectives by some high-profile companies like Dick Smith, China Medical Technologies (CMED), Banco Espirito Santo (BES), Volkswagen AG and Dynegy (Hamzah et al., 2018; Ivan, 2019; Lei \& Chen, 2019). It is unremarkable that the existence of these global ethical debacles cast doubt on stakeholders and investors' confidence, which afflict firm value and potential investment decision making (Godlewska \& Pilewicz, 2018; Nakpodia et al., 2018; Primec \& Belak, 2018).

It is evident that insufficient accountability, unethical behaviour, and inefficiency of corporate governance structure has led to the corporations' financial failure (Karaca et al., 2018; Nikolić \& Zlatanović, 2018; Surbhi \& Vij, 2018). Consequently, a U.S. federal law called Sarbanes-Oxley Act was enacted in 2002, and ethical standards are primarily interested in every firm within the context of corporate governance logic. In contributing to this, accounting fraud, poor disclosure and transparency had stimulated regulatory interest in ethics and subsequently, the International Accounting Education Standards Board (IAESB) was developed in the year 2003 by establishing standards that prescribe technical competence and professional skills, ethics, and attitudes to strengthen public trust.
Although there is a rich body of literature in understanding corporate governance, it has become too centred and, in turn, pays less attention to the individual intention towards unethical individual behaviour. In addition, influential studies report the inconsistency of literature review in ethical behaviour. Thus, the purpose of this study seeks to underpin the conceptual framework towards ethical judgement and to delineate better the relationships between personality traits and morally ethical behaviour. Furthermore, this research also seeks to provide suggestions for the firms on selecting key personnel to ensure success therein. Therefore, the Theory of Planned Behaviour and Moral norms work with this construct, followed by research methodology, findings, and key contributions for future studies.

\section{LITERATURE REVIEW}

\section{Theory of Planned Behaviour}

Theory of Planned Behaviour (TPB) is a social-psychological theory used to explain and predict an individual's intentional behaviour. As such, this theory is wellknown and widely applied to the studies among attitude, relativism, consumer ethics and behaviour (Bairaktarova \& Woodcock, 2017; Ferencz-Kaddari et al., 2016; Hashim et al., 2018). To further illustrate, TPB consists of three main constructs: attitude toward the behaviour, subjective norm, and perceived behavioural control. Attitude toward a behaviour is defined as an individual's perceptions towards an event or activity based on his/her perceptions, beliefs, observations, past experiences, and 
availability of information (Chang \& Chou, 2018; Ferencz-Kaddari et al., 2016; Jiang et al., 2018). On the other hand, subjective norm refers to an individual's perceptions towards the expectations of recommended behaviour from the third parties (family members, friends, peers, and society). Finally, as for perceived behavioural control, it explains the perception of an individual on his/her ability to overcome the difficulties and consequences (legally or reaction from society) of the suggested behaviour.

In relation to this research, attitude toward TPB behaviour accounts for the influence of an individual's moral judgment in engaging in ethical/unethical intention in decision making (Baden, 2014; Zaman et al., 2018). To further describe, ethics (moral philosophy) refers to the moral principles that govern the concepts of right and wrong conduct. Thus, an individual with a low level of ethical concern is highly likely to engage in unethical behaviour.

\section{Moral Norms and Moral Judgement}

Moral norms are the rules and obligations of morality that people ought to follow. The norms provide people with the breadth and depth for moral judgement by adequately guiding people what is right and good in moral dilemmas (Maffini \& KimJu, 2018; Mansori, Rezaee et al., 2015; Yusupova, 2018). In the same vein, moral norms can be applied with the Theory of Planned Behaviour (attitude) to predict an individual's intentional behaviour better. With that being said, an individual with a high level of moral obligation may exhibit ethical decision making and vice versa.
On the other hand, moral judgement is defined as a state of belief, a judgement of moral values that can be used to evaluate an individual's ethical behaviour in a given situation (Breakey, 2018; Moncrieff \& Lienard, 2018; Proctor et al., 2017). From the broader viewpoint, moral judgement is accompanied by moral obligation and moral sentiment. It is, therefore, safe to consider that an individual perceives a particular behaviour as right when he/she feels that there is a moral obligation (moral norms) beneath (Henrich et al., 2017; Maffini \& Kim-Ju, 2018; Ward \& King, 2018; Wegner et al., 2019). Thus, along with the feeling of approval (moral judgement), eventually, the individual tends to exhibit morally salient behaviour.

Regarding the above, TPB and moral norms advocate that attitude and moral obligations might be influenced by personality traits (people's characteristics), which in turn can influence moral judgement and potential intended behaviour (Grosby, 2015; Yacob et al., 2018). However, little research focuses on the ethical and moral factors influencing an individual's moral judgement and behavioural intention. As a result, this study seeks to evaluate the relationships between religiosity, ethnicity, and gender identification towards moral judgement with the inclusion of selftranscendence as a mediator.

\section{Religiosity}

In essence, religiosity portrays the degree of an individual's belief in God, his/her adherence to the religious practices and 
values applied in his/her daily routine (Breakey, 2018; Yacob et al., 2018). Different studies have revealed that religiosity significantly impacts an individual's attitude and intended behaviour (TPB) to enhance this provision. Correspondingly, religiosity is validated as an integral role in influencing an individual's level of religiosity adherence towards moral judgement and ethical decision making (Hashim et al., 2018; Jiang et al., 2018). In this context, if a person has high religiosity, he/she may tend to exhibit more ethical behaviour. Thus, to test the relationship between religiosity and moral judgement, the hypothesis is developed below:

H1: There is a relationship between religiosity and self-transcendence towards ethical, moral judgement.

\section{Ethnicity}

Ethnicity can be defined as an individual's behaviour and self-concept, which is directly influenced by his/her membership of a social group and the value and emotional significance attached to that membership (Grosby, 2015; Moncrieff \& Lienard, 2018; Yusupova, 2018). By and large, ethnicity is presumed to have a crucial role in influencing a person's ethics and moral obligations. However, little research proposed the impact of ethnicity on a person's attitude and ethical-moral judgment. As opposed to this viewpoint, the concept of the social norm social in Theory of Planned Behaviour (TPB) explains that a person tends to engage in a recommended behaviour which is suggested by his/her social group or close ones (family members, friends, siblings; Bairaktarova \& Woodcock, 2017; FerenczKaddari et al., 2016; Zaman et al., 2018). Hence, it is argued that ethnicity might be linearly associated with ethical decision making. In brief, to justify the relationship between ethnicity and moral judgement, the following hypothesis has been derived:

H2: There is a relationship between ethnicity and self-transcendence towards ethical, moral judgement.

\section{Gender Identification}

Gender identity can be defined as an individual sense of own self-identified gender. Gender identity can have a high level of correlation with the person sex at birth as in many societies; the underlying assumption is that a man should be masculine, and a woman should behave in a femininely. However, pioneer scholars such as Stoller (1964) tried to differentiate natural sex labelling from gender-based behaviour's related behavioural and psychological aspects by introducing gender identity terms (Turban \& Ehrensaft, 2018).

Recently, the question of measuring gender differences in ethical decision making has raised research interest worldwide. In this concept, rigorous studies reported that moral issues arise due to the different modes of thinking between men and women. For example, some studies show that men tend to justify moral issues in terms of rules and rights (Nguyen et al., 2016; Wang \& Calvano, 2013; Zayer \& Coleman, 2015). In contrast, women tend to justify moral issues in terms of feelings and relationships. 
A group of researchers proposed that women are more unselfish, emphatic, exhibit higher moral sensitivity and, thus, have lesser intention to engage in unethical behaviour than men (Bossuyt \& Van Kenhove, 2016; Chen et al., 2016; Jereb et al., 2018). Also, other studies found that there is no gender difference in moral beliefs. It is, therefore, safe to consider that there is an inconsistency of conceptual framework towards ethical, moral judgement. Based on the findings, to test the relationship between gender difference and ethical-moral judgement, the hypothesis is conducted below:

H3: There is a relationship between gender difference and self-transcendence towards ethical, moral judgement.

\section{Basic Human Values}

Theory of Basic Human Values (TBHV) is commonly used to measure universal values recognised by almost all individuals. Utilising this theory encompasses ten motivationally distinct values, and these values are divided into a total of four dimensions: openness to change (stimulation, selfdirection), self-transcendence (benevolence, universalism), conservation (security, conformity, tradition) and self-enhancement (hedonism, achievement, power; Magun et al., 2017; Seddig \& Davidov, 2018; Tevrüz et al., 2015). In addition, self-transcendence is emphasised in this study to enhance this explanation. Given that, it epitomises the attitude of tolerance, appreciation, the values of concern and protection for the welfare of others.
By considering TBHV and Theory of Planned Behaviour (TPB), individuals generally should be motivated by their social groups (social norm and benevolence), and it is presumed that they tend to appreciate and accept the values/beliefs (universalism) shared by those who are in the same social group (Ariza-Montes et al., 2017; Pohling et al., 2016; Różycka-Tran et al., 2017). It is being said that values affect attitude, perceptions, intention and subsequently, behaviour. Likewise, if the behaviour of a person in the group shows the value of selftranscendence, he/she will facilitate others' moral cognition processes (benevolence) and eventually influence their attitude and intended behaviour (Baden, 2014; Jiang et al., 2018). The following hypothesis is proposed to test the relationship between self-transcendence and ethical-moral judgement:

H4: There is a relationship between self-transcendence and ethical-moral judgement.

\section{Mediation Effect}

Self-transcendence is employed in this research as a mediating variable to examine key attributes' impact on ethical moral judgment. To further illustrate, a mediating variable is termed as an intervening variable that seeks to justify the mechanism of the relationships between the independent variables (religiosity, ethnicity, and gender identification) and the dependent variable (moral judgement; Figure 1). As such, its intervention will affect the significance between these variables. However, 


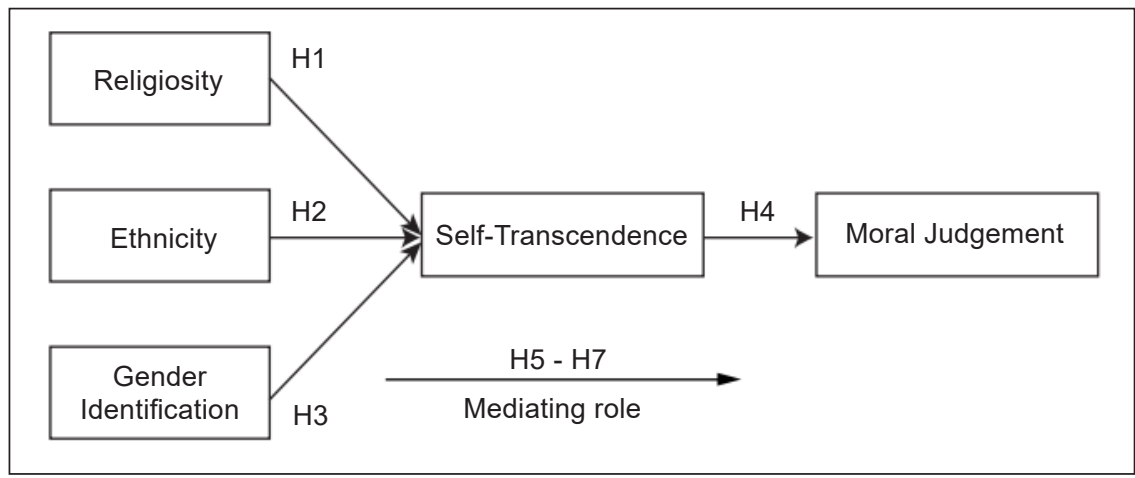

Figure 1. Proposed conceptual framework

inconsistent findings were found with the limitation in using self-transcendence as a mediator for moral-salient behaviour. As a result, it is hypothesised that selftranscendence should trigger a person's ethical, moral judgement and thus, the following hypotheses have been designed:

H5: Self-transcendence mediates the relationship between religiosity and ethical-moral judgement.

H6: Self-transcendence mediates the relationship between ethnicity and ethical-moral judgement.

H7: Self-transcendence mediates the relationship between gender identification and ethical-moral judgement.

\section{METHODOLOGY}

During the data collection process, 300 self-administrated questionnaires were distributed. Students pursuing an undergraduate degree in Business, Recourse Management, Marketing, Human Management Finance and Accounting programmes from three private and two public universities in Malaysia were selected using non-probability convenience sampling.

The developed questionnaire consists of two sections. Section A is inquiries about religiosity, ethnicity, gender identity, selftranscendence, and moral judgments (please see Table 2 for more details). Section B asks for participants' demographic information. As authors tried to minimise any overgeneralisation of findings by creating any prejudice, the nationality, ethnic group and religious affiliation of participants are not asked and not included in this part.

To measure the level of religiosity, gender identity, and ethnicity, participants rated their disagreement and agreement level with the statements (1; "Strongly Disagree" and 6: "Staringly Agree"). The self-transcend measurement is adapted from the Portrait Values Questionnaire (PVQ; Schwartz et al., 2001). In this part, participants were asked to rate their similarities with the provided statements (1; "Not Like Me at All" and 6; "Very Much Like Me").

Five potential scenarios developed by Reidenbach and Robin (1990) were 
adopted to measure the moral judgment of participants. This part evaluated four moral judgement's dimensions (Contractualism, Moral Equity, Relativism and Universalism). The value of each dimension was calculated based on the mean score (reversed) of all five scenarios (Please see appendix A). As the used questions for some constructs have male and female versions and to avoid confusion for participants, two copies of the questionnaire (Male and Female) were passed to participants, and they have full liberty to choose the version that their wish to answer based on their preference (unused questionnaires were discarded.

\section{DATA ANALYSIS}

Some of the returned questionnaires were filtered out due to the missing values and incomplete answers. As a result, a total of 251 samples were finalised for data analysis. According to Table 1, 39.8\% of the participants are majoring in accounting, whilst finance stands for $29.5 \%$, followed by other majors (11.2\%). Similarly, the fourth ranking falls to management $(8.4 \%)$, and the fifth is marketing (4.0\%). On the other hand, more than half of the participants are in year $2(57.8 \%)$, and $21.9 \%$ are in year 1. Additionally, the data shows that approximately $76.5 \%$ of the participants have learnt about ethics whilst $23.5 \%$ have not.

Based on the reliability and validity analysis shown below (Table 2), the developed measurement model has presumed to fit as it is within the acceptable level of reliability and validity measurement. To further explain, the Factor Loading and Average Variance Extracted (AVE) of all variables are more than 0.5 respectively (0.643-0.865 and 0.526-0.674) and thus, it is within the acceptable range. On the other hand, Composite Reliability (CR) and Cronbach's Alpha (CA) are within the level of acceptance as both values exceed 0.7 (ranging between 0.816- 0.912 and 0.7260.880 , respectively).

By adhering to this, the path model below (Figure 2) exhibits three independent variables (religiosity, ethnicity, and gender identification) towards moral judgement with the mediation effect of self-transcendence.

According to Table 3 below, religiosity presents a significant direct relationship

Table 1

Demographic information

\begin{tabular}{lccccc}
\hline Major & $\mathbf{\%}$ & Academic Year & $\mathbf{\%}$ & Pass any Ethics Course & $\mathbf{\%}$ \\
\hline Accounting & 39.8 & Year 1 & 21.9 & Yes & 76.5 \\
Finance & 29.5 & Year 2 & 57.8 & No & 23.5 \\
Marketing & 4.0 & Year 3 & 14.3 & & \\
Human Resource & 1.6 & Year 4 & 6.0 & Gender & Male \\
Management & 8.4 & & & Female & 49.0 \\
Business & 3.2 & & & & 51.0 \\
Law & 2.4 & & & & \\
Other & 11.2 & & & & \\
\hline
\end{tabular}


Table 2

Reliability and validity analysis

\begin{tabular}{|c|c|c|c|c|}
\hline Religiosity & $\begin{array}{l}\text { Average extracted } \\
\text { Variance (AVE) }\end{array}$ & $\begin{array}{l}\text { Composite reliability } \\
\text { (CR) }\end{array}$ & Cronbach's alpha (CA) & $\begin{array}{l}\text { Factor } \\
\text { loading }\end{array}$ \\
\hline & 0.674 & 0.912 & .880 & \\
\hline \multicolumn{4}{|c|}{$\begin{array}{l}\text { Religion is especially important to me because it answers many questions about the meaning of } \\
\text { life }\end{array}$} & 0.768 \\
\hline \multicolumn{4}{|c|}{ I try to follow my religious beliefs in all aspects of life } & 0.865 \\
\hline \multicolumn{4}{|c|}{ Prayers and reflections of my religious thought make me calm } & 0.806 \\
\hline \multicolumn{4}{|c|}{ Religious beliefs influence all my dealings in life } & 0.831 \\
\hline \multicolumn{4}{|c|}{ I enjoy spending time reading and learning more about my religion } & 0.832 \\
\hline \multicolumn{5}{|c|}{ Adopted/Adapted from: Mansori, Sambasivan et al. (2015) } \\
\hline \multirow[t]{2}{*}{ Ethnicity } & $\begin{array}{l}\text { Average extracted } \\
\text { Variance (AVE) }\end{array}$ & $\begin{array}{l}\text { Composite } \\
\text { reliability }(\mathrm{CR})\end{array}$ & $\begin{array}{l}\text { Cronbach's } \\
\text { Alpha (CA) }\end{array}$ & $\begin{array}{l}\text { Factor } \\
\text { loading }\end{array}$ \\
\hline & 0.597 & 0.898 & .867 & \\
\hline \multicolumn{4}{|c|}{ I feel a strong attachment towards my ethnic group. } & 0.773 \\
\hline \multicolumn{4}{|c|}{ I have often talked to other people to learn more about my ethnic group. } & 0.855 \\
\hline \multicolumn{4}{|c|}{ I have often done things that will help me understand my ethnic background better. } & 0.819 \\
\hline \multicolumn{4}{|c|}{ I understand pretty well what my ethnic group membership means to me. } & 0.834 \\
\hline \multicolumn{4}{|c|}{ I have a strong sense of belonging to my ethnic group. } & 0.690 \\
\hline \multicolumn{4}{|c|}{$\begin{array}{l}\text { I have spent time trying to find out more about my ethnic groups, such as their history, } \\
\text { traditions, and customs. }\end{array}$} & Removed \\
\hline \multicolumn{5}{|c|}{ Adopted/Adapted from: Phinney \& Ong (2007) } \\
\hline \multirow[t]{2}{*}{$\begin{array}{l}\text { Gender } \\
\text { Identification }\end{array}$} & $\begin{array}{l}\text { Average extracted } \\
\text { Variance (AVE) }\end{array}$ & $\begin{array}{l}\text { Composite } \\
\text { reliability }(\mathrm{CR})\end{array}$ & $\begin{array}{l}\text { Cronbach's } \\
\text { Alpha (CA) }\end{array}$ & $\begin{array}{l}\text { Factor } \\
\text { loading }\end{array}$ \\
\hline & 0.526 & 0.816 & .726 & \\
\hline \multicolumn{4}{|c|}{$\begin{array}{l}\text { When I'm with women, I want to impress, I try to act very feminine. } \\
\text { When I'm with men, I want to impress, I try to act very masculinely. * }\end{array}$} & 0.751 \\
\hline \multicolumn{4}{|c|}{$\begin{array}{l}\text { I prefer to defer to a man rather than trying to be his equal all the time. } \\
\text { I prefer a woman who defers to me rather than trying to be my equal all the time. * }\end{array}$} & 0.765 \\
\hline \multicolumn{4}{|c|}{$\begin{array}{l}\text { When there's an important job to be done, I'd prefer to have a man take the lead than a woman. } \\
\text { When there's an important job to be done, I'd prefer to have a man as a leader than a woman. * }\end{array}$} & 0.713 \\
\hline \multicolumn{4}{|c|}{$\begin{array}{l}\text { When men and women are in the same organisation, women should let the men take the lead } \\
\text { and not try to take over. }\end{array}$} & 0.669 \\
\hline \multicolumn{4}{|c|}{$\begin{array}{l}\text { When I'm with women, I want to impress, I try to act very feminine. } \\
\text { When I'm with men, I want to impress, I try to act very masculinely. * }\end{array}$} & Removed \\
\hline \multicolumn{5}{|c|}{$\begin{array}{l}\text { Adopted/Adapted from: Spence \& Helmreich (1980) } \\
\text { *For Male Participants. }\end{array}$} \\
\hline \multirow[t]{2}{*}{$\begin{array}{l}\text { Self- } \\
\text { Transcendence }\end{array}$} & $\begin{array}{l}\text { Average extracted } \\
\text { Variance (AVE) }\end{array}$ & $\begin{array}{c}\text { Composite } \\
\text { reliability }(\mathrm{CR}) \\
\end{array}$ & $\begin{array}{l}\text { Cronbach's } \\
\text { Alpha (CA) }\end{array}$ & $\begin{array}{l}\text { Factor } \\
\text { loading }\end{array}$ \\
\hline & 0.543 & 0.892 & .859 & \\
\hline \multicolumn{4}{|c|}{$\begin{array}{l}\text { She thinks it is important that every person in the world be treated equally. She believes } \\
\text { everyone should have equal opportunities in life. } \\
\text { He thinks it is important that every person in the world be treated equally. He believes } \\
\text { everyone should have equal opportunities in life. * }\end{array}$} & 0.667 \\
\hline
\end{tabular}


Table 2 (continue)

\begin{tabular}{lcccc}
\hline $\begin{array}{l}\text { Self- } \\
\text { Transcendence }\end{array}$ & $\begin{array}{c}\text { Average extracted } \\
\text { Variance (AVE) }\end{array}$ & $\begin{array}{c}\text { Composite } \\
\text { reliability (CR) }\end{array}$ & $\begin{array}{c}\text { Cronbach's } \\
\text { Alpha (CA) }\end{array}$ & $\begin{array}{c}\text { Factor } \\
\text { loading }\end{array}$ \\
\hline & 0.543 & 0.892 & .859 & \\
\hline
\end{tabular}

It is important for her to respond to the needs of others. She tries to support those she knows.

It is important for him to respond to the needs of others. He tries to support those he knows. *

She wants everyone to be treated justly, even people she doesn't know. It is important to her to protect the weak in society.

He wants everyone to be treated justly, even people he doesn't know. It is important to him to protect the weak in society. *

It's very important to her to help the people around her. She wants to care for their well-being. It's very important to him to help the people around him. He wants to care for their well-being.

It is important to her to be loyal to her friends. She wants to devote herself to people close to her.

It is important to him to be loyal to his friends. He wants to devote himself to people close to him. *

Forgiving people who have hurt her is important to her. She tries to see what is good in them and not hold a grudge.

Forgiving people who have hurt him is important to him. He tries to see what is good in them and not hold a grudge. *

It is important to her to adapt to nature and to fit into it. She believes that people should not change nature.

It is important to him to adapt to nature and to fit into it. He believes that people should not change nature. *

She strongly believes that people should care for nature. Looking after the environment is important to her.

He strongly believes that people should care for nature. Looking after the environment is important to him. *

\begin{tabular}{|c|c|c|c|c|}
\hline \multicolumn{5}{|c|}{$\begin{array}{l}\text { Adopted/Adapted from: Schwartz et al. (2001) } \\
\text { *For Male Participants. }\end{array}$} \\
\hline Moral Judgement & $\begin{array}{l}\text { Average extracted } \\
\text { Variance (AVE) }\end{array}$ & $\begin{array}{l}\text { Composite } \\
\text { reliability }(\mathrm{CR})\end{array}$ & $\begin{array}{l}\text { Cronbach's } \\
\text { Alpha (CA) }\end{array}$ & $\begin{array}{l}\text { Factor } \\
\text { loading }\end{array}$ \\
\hline & 0.593 & 0.879 & .830 & \\
\hline Contractualism & & & & 0.812 \\
\hline Moral Equity & & & & 0.772 \\
\hline Relativism & & & & 0.673 \\
\hline Universalism & & & & 0.786 \\
\hline \multicolumn{5}{|c|}{ Adopted/Adapted from: Reidenbach \& Robin, 1990} \\
\hline Items with factor lo & ling below 0.60 are & & & \\
\hline
\end{tabular}

towards self-transcendence, and thus, it is person to perform ethical, moral judgement. supported $(H 1)(\beta=0.243, \mathrm{~T}$-value=3.408). In relation to hypothesis $2(H 2)$, there is a Given that, this hypothesis 1 concludes significant positive relationship (supported) that the higher level of religiosity and self- between ethnicity and self-transcendence transcendence, the higher tendency of a $(\beta=0.253$, T-value $=2.883)$. Specifically, if a 


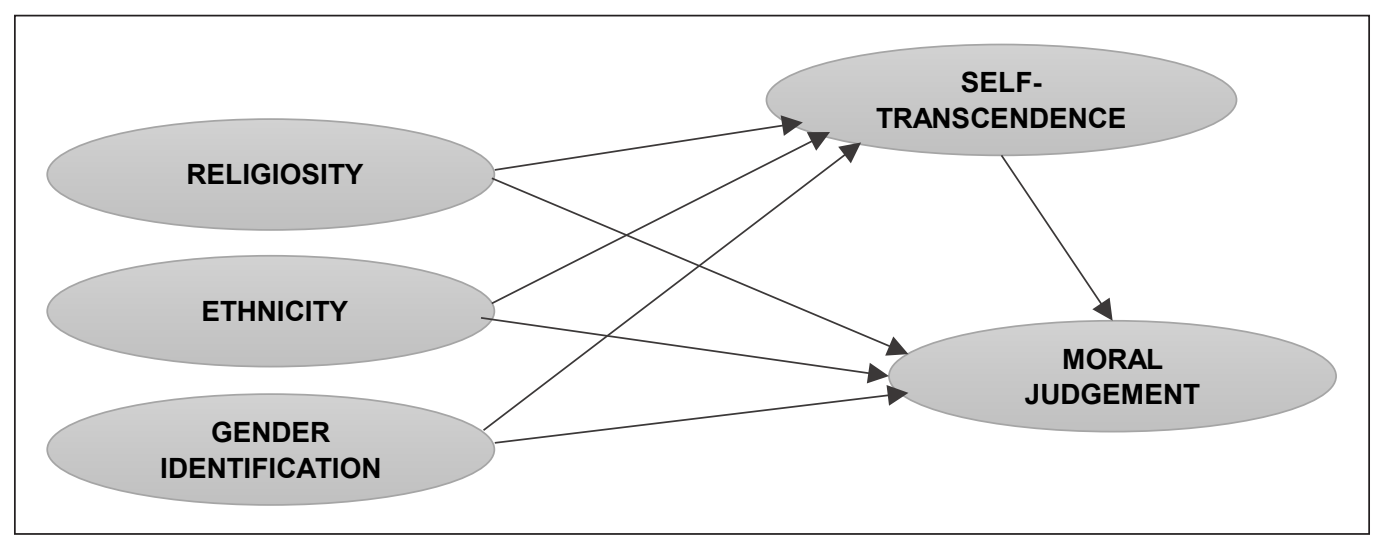

Figure 2. Path model with self-transcendence as mediating variable

Table 3

Hypothesis testing

\begin{tabular}{|c|c|c|c|c|}
\hline $\begin{array}{l}\text { Hypothesis } \\
\text { (Direct relationship) }\end{array}$ & $\begin{array}{l}\text { Sample } \\
\text { mean } \beta\end{array}$ & $\begin{array}{l}\text { Standard } \\
\text { deviation }\end{array}$ & $\begin{array}{l}\text { T statistics }(\mathrm{T}> \\
1.96=\mathrm{p}<0.05)\end{array}$ & Supported \\
\hline $\begin{array}{l}\text { H1: Religiosity } \\
\text { Self-transcendence }\end{array}$ & 0.243 & 0.072 & 3.408 & Yes \\
\hline $\begin{array}{l}\text { H2: Ethnicity } \\
\text { Self-transcendence }\end{array}$ & 0.253 & 0.086 & 2.883 & Yes \\
\hline H3: Gender Identification $\square$ Self-transcendence & 0.140 & 0.061 & 2.208 & Yes \\
\hline H4: Self-transcendence $\mathrm{Q}$ Moral Judgement & 0.290 & 0.065 & 4.487 & Yes \\
\hline \multicolumn{5}{|c|}{$\begin{array}{l}\text { R-square: } \\
\text { Self-transcendence: } 0.263 \text {, Moral Judgement: } 0.356\end{array}$} \\
\hline
\end{tabular}

person has a high degree of ethnicity, he/she will most likely exhibit ethical behaviour. Along with this table, gender identification (H3) also shows a significant positive relationship towards ethical decision making with the values of $\beta=0.140, T-$ value $=2.208$ and hence, it is supported.

Associated with $H 3$, it is assumed that males (masculinity) have a higher tendency of engaging in unethical moral judgement than females (femininity) due to the different modes of moral justification. As for hypothesis $4(H 4)$, there is a significant direct relationship between self-transcendence and moral judgement (supported with $\beta=0.290$,
T-value $=4.487)$. Thus, it can be explained that the higher level of self-transcendence in a person, the higher level of ethical engagement of him/her.

To achieve better understanding, the $\mathrm{R}^{2}$ for self-transcendence is $0.263(26.3 \%)$, whilst moral judgement's $\mathrm{R}^{2}$ is 0.356 (35.6\%). It illustrates that a $26.3 \%$ variance of self-transcendence can be justified by the independent variables (religiosity, ethnicity and gender identification), and a $35.6 \%$ variance of modal judgement can be explained by self-transcendence.

In addition, to test the mediating effect of self-transcendence, the bootstrapping 
Table 4

Test of total effect using bootstrapping

\begin{tabular}{lcccc}
\hline Path c' & $\begin{array}{c}\text { Sample } \\
\text { mean } \beta\end{array}$ & $\begin{array}{c}\text { Standard } \\
\text { deviation }\end{array}$ & $\begin{array}{c}\text { T statistics } \\
(\mathrm{T}>1.96=\mathrm{p}<0.05)\end{array}$ & Supported \\
\hline H5: Religiosity Q Moral Judgement & -0.119 & 0.108 & 1.067 & No \\
$\begin{array}{l}\text { H6: Ethnicity M Moral } \\
\text { Judgement }\end{array}$ & 0.360 & 0.105 & 3.429 & Yes \\
H7: Gender Identification Q Moral Judgement & 0.354 & 0.057 & 6.044 & Yes \\
\hline
\end{tabular}

Table 5

Test of the indirect effect

\begin{tabular}{lccc}
\hline Total indirect effect & P-value & $\begin{array}{c}\text { T statistics } \\
(\mathrm{T}>1.96=\text { partial })\end{array}$ & Mediation effect \\
\hline Ethnicity D Moral Judgement & .007 & 1.765 & Yes- Full mediation \\
Gender Identification P Moral Judgement & .015 & 2.731 & Yes- Partial mediation \\
\hline
\end{tabular}

method was employed. The results (Tables 4 and 5) show that self-transcendence mediates the relationship between ethnicity, gender identification and moral judgment. With that being said, both $\mathrm{H} 6$ and $H 7$ propose significant relationships for ethnicity and gender identification towards moral judgement $(\beta=0.360$, T-value $=3.429$; $\beta=0.354$, T-value $=6.044$ respectively). Relatively, this reveals that selftranscendence mediates in these hypotheses with a partial mediation effect $(\mathrm{T}$-value $=$ 2.731 for ethnicity; $\mathrm{T}-\mathrm{value}=5.278$ for gender identification). Opposed, $H 5$ is not supported as there is an insignificant relationship between religiosity and moral judgement $(\beta=-0.119, \mathrm{~T}$-value $=1.067)$.

\section{FINDINGS AND DISCUSSION}

The above findings show that there is a strong direct correlation between ethnicity and selftranscendence. This result can be explained by the Theory of Planned Behaviour (TPB) as based on TBP person's moral judgement can be influenced by attitude, social norm(s) and perceived behavioural control of his/her ability to perform moral obligations. In other words, if a person has a strong tight with his/ her ethnic group that holds the value and belief of ethical judgement, highly likely, he/she will follow and maintain this group's common values.

This result can be used as a guideline for corporations and universities to design and develop training programmes that highlight unethical behaviour's the negative impact and detriments towards society and the community. Additionally, the benefits of engaging in ethical behaviour should be nudged to the public to build a moral direction therein. Given that, ethics awareness will grow and spread among the society in the long term.

On the other hand, the current results show that the level of religiosity has a direct association with the level of selftranscendence. It is important to be considered that there is a difference between 
religiosity/spirituality with some extreme interpretations of religions which can be observed in some societies. The main focus of this study's instrument to measure the participants' religiosity is intrinsic (the use of religion without social pressure and/ or gain) than extrinsic religiosity (use of religion to gain social acceptance). These results can enhance programmes/modules in ethics and corporate governance fields by adding more spirituality related content into the developed curricula.

Furthermore, the current results reveal that gender identification has a positive relationship with self-transcendence and moral judgment. Gender identification in this study refers to an individual sense of own self-identified gender. In this study, participants have full liberty to choose the type of questionnaire that they wish to answer based on their sense of identification towards their gender. Thus, there is a possibility that some individuals that chose to answer the male (or female) version of the questionnaire were from the opposite birth sex. As a result, these findings should be interpreted in a way that higher gender identification based on self-identified gender has a direct and positive relationship with self-transcendence and moral judgment (not simply are interpreted as masculine males or feminine females may show a higher level of self-transcendence and moral judgment). As a result, training and professional development programmes should be provided in the corporations to train both male and female employees. In addition, hypothetical ethical scenarios should be included in the training sessions to learn through the different modes of thinking and moral obligations.

Positive psychology and the moral conation process should be emphasised in future research to enhance understanding of taking a person to make a moral judgment. Secondly, employers should seek value profiles during interviews. Given an example, knowing which values (personal traits) should be endorsed by a potential employee so that these ethical values could assist his/her working performance if he/ she is successfully hired. In essence, ethical values and moral obligations should be highlighted in corporations, and these values should be practised and embraced into the organisational culture. Thus, organisational decision-makers should highly emphasise the role of ethicality and morality in corporations because ethical competence aligns with an employee's responsibility as a whole.

\section{CONCLUSION}

Several business scandals have occurred in the recent years mainly because of a weaker corporate governance structure and lack of sufficient accountability. Some studies argued that more restricted regulations and governance procedures can reduce the chance of unethical behaviour at the corporate level. While other research highlighted that more restricted regulations pre se might not be effective and discussed the contribution of moral and ethical educations in reducing the chance of corporate wrongdoing. The findings of this study indicate that ethnicity has the highest 
impact on self-transcendence and moral judgement, followed by religiosity and gender identification. In essence, ethical values and moral obligations should be highlighted in training and professional development programmes, and these values should be practised and embraced into the organisational culture.

Same as any other empirical study, this study's results should also be generalised by considering the below-mentioned limitations. In addition, the provided suggestion can be useful to improve the further studies' results in this field. 1) the samples in this study were selected based on non-probability sampling and from a limited number of universities in Malaysia. Therefore, it is advisable if further studies can have a multinational approach and collect samples from different countries and test the moderating effect of other cultural dimensions such as power distance, individualism/collectivism, and long-term/short-term orientation. 2) the coefficient of determinations of the study are $\mathrm{R}_{\text {(Self-transcendence) }}^{2}=0.263$ and $\mathrm{R}_{\text {(Moral Judgement) }}=$ 0.356 , which shows that the current model can predict $26.3 \%$ and $35.6 \%$ of Selftranscendence and Moral Judgement As a result, further studies can consider including other variables from the Theory of Basic Human Values to improve predictability. 3) As exploratory and quantitative research, this study could not deeply explore the means and justifications of provided responses by participants. Accordingly, having more exploratory qualitative studies in the future can shade more light on this phenomenon.

\section{ACKNOWLEDGEMENT}

The authors would like to thank all their colleagues and associates who assisted them during the data collection process and all experts who shared insight and expertise that greatly assisted the research, although they may not agree with all of the interpretations/ conclusions of this paper.

\section{REFERENCES}

Ariza-Montes, A., Arjona-Fuentes, J. M., Han, H., \& Law, R. (2017). Employee responsibility and basic human values in the hospitality sector. International Journal of Hospitality Management, 62, 78-87. https://doi. org/10.1016/j.ijhm.2016.12.001

Baden, D. (2014). Look on the bright side: A comparison of positive and negative role models in business ethics education. Academy of Management Learning and Education, 13(2), 154-170. https://doi.org/10.5465/ amle.2012.0251

Bairaktarova, D., \& Woodcock, A. (2017). Engineering student's ethical awareness and behavior: A new motivational model. Science and Engineering Ethics, 23(4), 1129-1157. https://doi.org/10.1007/s11948-016-9814-x

Bossuyt, S., \& Van Kenhove, P. (2016). Assertiveness bias in gender ethics research: Why women deserve the benefit of the doubt. Journal of Business Ethics, 150(3), 727-739. https://doi. org/10.1007/s10551-016-3026-9

Breakey, H. (2018). Same duties, different motives: Ethical theory and the phenomenon of moral motive pluralism. Philosophical Studies, 175(2), 531-552. https://doi.org/10.1007/s11098-0170881-x

Chang, S. H., \& Chou, C. H. (2018). Consumer intention toward bringing your own shopping bags in Taiwan: An application of ethics 
perspective and theory of planned behavior. Sustainability (Switzerland), 10(6). https://doi. org/10.3390/su10061815

Chen, C., Tuliao, K. V., Cullen, J. B., \& Chang, Y. Y. (2016). Does gender influence managers' ethics? A cross-cultural analysis. Business Ethics, 25(4), 345-362. https://doi.org/10.1111/beer.12122

Ferencz-Kaddari, M., Shifman, A., \& Koslowsky, M. (2016). Modeling psychologists' ethical intention. Psychological Reports, 118(3), 691709. https://doi.org/10.1177/0033294116647691

Godlewska, M., \& Pilewicz, T. (2018). The impact of interplay between formal and informal institutions on corporate governance systems: A comparative study of CEECs. Comparative Economic Research, 21(4), 85-104. https://doi. org/10.2478/cer-2018-0028

Grosby, S. (2015). Myth and symbol: The persistence of ethnicity and religion: John Armstrong and nationality. Nations and Nationalism, 21(1), 182186. https://doi.org/10.1111/nana.12107

Hamzah, A. H., Zulkafli, A. H., \& Tapa, A. (2018). Corporate expropriation from the perspective of non-contestability of ownership structure and corporate governance. Global Business \& Management Research, 10(3), 403-418.

Hashim, M. J., Kannan, K. N., \& Wegener, D. T. (2018). Central role of moral obligations in determining intentions to engage in digital piracy. Journal of Management Information Systems, 35(3), 934-963. https://doi.org/10.108 0/07421222.2018.1481670

Henrich, N. J., Dodek, P. M., Gladstone, E., Alden, L., Keenan, S. P., Reynolds, S., \& Rodney, P. (2017). Consequences of moral distress in the intensive care unit: A qualitative study. American Journal of Critical Care, 26(4), 48-57. https:// doi.org/10.4037/ajec2017786

Ivan, O. R. (2019). Integrated reporting in the context of corporate governance. Case study on the adoption of integrated reporting of Romanian companies listed on BSE. Valahian Journal of Economic Studies, 9(2), 127-138. https://doi. org/10.2478/vjes-2018-0024

Jereb, E., Urh, M., Jerebic, J., \& Šprajc, P. (2018). Gender differences and the awareness of plagiarism in higher education. Social Psychology of Education, 21(2), 409-426. https:// doi.org/10.1007/s11218-017-9421-y

Jiang, Y., Xiao, L., Jalees, T., Naqvi, M. H., \& Zaman, S. I. (2018). Moral and ethical antecedents of attitude toward counterfeit luxury products: Evidence from Pakistan. Emerging Markets Finance and Trade, 54(15), 3519-3538. https:// doi.org/10.1080/1540496X.2018.1480365

Karaca, S. S., Şenol, Z., \& Korkmaz, Ö. (2018). Mutual interaction between corporate governance and enterprise risk management: A case study in Borsa Istanbul Stock Exchange. Journal of Accounting \& Finance, (78), 235-248. https:// doi.org/10.25095/mufad.412709

Lei, Q., \& Chen, H. (2019). Corporate governance boundary, debt constraint, and investment efficiency. Emerging Markets Finance and Trade, 55(5), 1091-1108. https://doi.org/10.108 0/1540496X.2018.1526078

Maffini, C. S., \& Kim-Ju, G. M. (2018). Fighting and bullying among Asian Americans and Latinos: Testing the roles of self-efficacy, ethnic identity, and ethnicity. Youth and Society, 50(8), 1019-1036. https://doi. org/10.1177/0044118X16630560

Magun, V., Rudnev, M., \& Schmidt, P. (2017). A typology of European values and Russians' basic human values. Russian Social Science Review, 58(6), 509-540. https://doi.org/10.1080/106114 28.2017 .1398547

Mansori, S., Rezaee, Z., Homayoun, S., \& Noghondari, A. T. (2015). Do individual traits associate with ethical judgment? Journal of Management 
and Sustainability, 5(3), 85-98. https://doi. org/10.5539/jms.v5n3p85

Mansori, S., Sambasivan, M., \& Md-Sidin, S. (2015). Acceptance of novel products: The role of religiosity, ethnicity and values. Marketing Intelligence \& Planning, 33(1), 39-66. https:// doi.org/10.1108/MIP-03-2013-0050

Moncrieff, M. A., \& Lienard, P. (2018). Moral judgments of in-group and out-group harm in post-conflict urban and rural Croatian communities. Frontiers in Psychology, 9(Feb). https://doi.org/10.3389/fpsyg.2018.00212

Nakpodia, F., Adegbite, E., Amaeshi, K., \& Owolabi, A. (2018). Neither principles nor rules: Making corporate governance work in sub-saharan Africa. Journal of Business Ethics, 151(2), 391408. https://doi.org/10.1007/s10551-016-3208-5

Nguyen, L. D., Ermasova, N., \& Ermasov, S. (2016). Business ethics perceptions of Russian working adults: Do age, gender, education, and various work experiences make a difference? S.A.M. Advanced Management Journal, 81(1), 4-19.

Nikolić, J., \& Zlatanović, D. (2018). Corporate governance and corporate social responsibility synergies: A systemic approach. Naše Gospodarstvo/Our Economy, 64(3), 36-46. https://doi.org/10.2478/ngoe-2018-0016

Phinney, J. S., \& Ong, A. D. (2007). Conceptualization and measurement of ethnic identity: Current status and future directions. Journal of Counseling Psychology, 54(3), 271. https://doi. org/10.1037/0022-0167.54.3.271

Pohling, R., Bzdok, D., Eigenstetter, M., Stumpf, S., \& Strobel, A. (2016). What is ethical competence? The role of empathy, personal values, and the five-factor model of personality in ethical decision-making. Journal of Business Ethics, 137(3), 449-474. https://doi.org/10.1007/s10551015-2569-5
Primec, A., \& Belak, J. (2018). Towards socially responsible corporate governance with authorities' interventions. Management (Croatia), 23(1), 203-219. https://doi.org/10.30924/ $\mathrm{mjcmi} / 2018.23 .1 .203$

Proctor, S. L., Kyle, J., Fefer, K., \& Lau, Q. C. (2017). Examining racial microaggressions, race/ ethnicity, gender, and bilingual status with school psychology students: The role of intersectionality. Contemporary School Psychology, 22(3), 355368. https://doi.org/10.1007/s40688-017-0156-8

Reidenbach, R. E., \& Robin, D. P. (1990). Toward the development of a multidimensional scale for improving evaluations of business ethics. Journal of Business Ethics, 9(8), 639-653. https://doi.org/10.1007/BF00383391

Różycka-Tran, J., Ha, T. T. K., Cieciuch, J., \& Schwartz, S. H. (2017). Universals and specifics of the structure and hierarchy of basic human values in Vietnam. Health Psychology Report, 3(3), 193-204. https://doi.org/10.5114/ hpr.2017.65857

Schwartz, S. H., Melech, G., Lehmann, A., Burgess, S., Harris, M., \& Owens, V. (2001). Extending the cross-cultural validity of the theory of basic human values with a different method of measurement. Journal of Cross-Cultural Psychology, 32(5), 519-542. https://doi. org/10.1177/0022022101032005001

Seddig, D., \& Davidov, E. (2018). Values, attitudes toward interpersonal violence, and interpersonal violent behavior. Frontiers in Psychology, 9(May), 1-13. https://doi.org/10.3389/ fpsyg.2018.00604

Spence, J. T., \& Helmreich, R. L. (1980). Masculine instrumentality and feminine expressiveness: Their relationships with sex role attitudes and behaviors. Psychology of Women Quarterly, 5(2), 147-163. https://doi. org/10.1111/j.1471-6402.1980.tb00951.x 
Stoller, R. J. (1964). The hermaphroditic identity of hermaphrodites. The Journal of Nervous and Mental Disease, 139(5), 453-457. https://doi. org/10.1097/00005053-196411000-00005

Surbhi, \& Vij, S. (2018). The interface of corporate governance with M\&A: Research themes. The IUP Journal of Business Strategy, 15(3), 19-38. https://ssrn.com/abstract=3313345

Tevrüz, S., Turgut, T., \& Çinko, M. (2015). Integrating Turkish work and achievement goals with Schwartz's human values. Europe's Journal of Psychology, 11(2), 259-279. https://doi. org/10.5964/ejop.v11i2.825

Turban, J. L., \& Ehrensaft, D. (2018). Research review: Gender identity in youth: Treatment paradigms and controversies. Journal of Child Psychology and Psychiatry, 59(12), 1228-1243. https://doi.org/10.1111/jcpp.12833

Wang, L. C., \& Calvano, L. (2013). Is business ethics education effective? An analysis of gender, personal ethical perspectives, and moral judgment. Journal of Business Ethics, 126(4), 591-602. https://doi.org/10.1007/s10551-0131973

Ward, S. J., \& King, L. A. (2018). Moral selfregulation, moral identity, and religiosity. Journal of Personality and Social Psychology, 115(3), 495-525. https://doi.org/10.1037/pspp0000207
Wegner, R., Roy, A. R., DaCova, A., \& Gorman, K. R. (2019). Similarities and differences in general drinking game behavior, game-specific behavior, and peer influence factors across race/ethnicity. American Journal of Orthopsychiatry, 89(5), 616. https://doi.org/10.1037/ort0000393

Yacob, Y., Ali, J. K., Roslin, R., \& Ting, H. (2018). The relationships between member participation, trust, Behavioural loyalty, and the moderating effect of ethnicity: An explanatory study of value co-creation among cooperative members in Sarawak. International Journal of Business and Society, 19(2), 505-522.

Yusupova, G. (2018). Making ethnic boundaries in the society of religious renaissance: Islam and everyday ethnicity in post-Soviet Tatarstan. National Identities, 20(4), 345-360. https://doi. org/10.1080/14608944.2016.1265493

Zaman, S. I., Jalees, T., Jiang, Y., \& Kazmi, S. H. A. (2018). Testing and incorporating additional determinants of ethics in counterfeiting luxury research according to the theory of planned behavior. Psihologija, 51(2), 163-196. https:// doi.org/10.2298/PSI170211014Z

Zayer, L. T., \& Coleman, C. A. (2015). Advertising professionals perceptions of the impact of gender portrayals on men and women: A question of ethics? Journal of Advertising, 44(3), 264-275. https://doi.org/10.1080/00913367.2014.975878 
Unfair (Moral Equity)

Unjust (Moral Equity)

Unacceptable (Moral Equity)

Morally wrong (Moral Equity)

Traditionally unacceptable (Relativism)

Culturally unacceptable (Relativism)

Violates an unspoken promise (Contractualism)

Violates an unwritten contract (Contractualism)

Ethically unacceptable (Universalism)
Fair

Just

Acceptable

Morally right

Traditionally acceptable

Culturally acceptable

Does not violate an unspoken promise

Does not violate an unwritten contract

Ethically acceptable

Scenario 5: Disclosure information

A chartered accountant of a public company knows about the highly positive results that will be shown to the stockholders.

Action: A company's chartered accountant, before the public disclosure of the corresponding results, called a personal friend advising him to buy stocks of that same company.

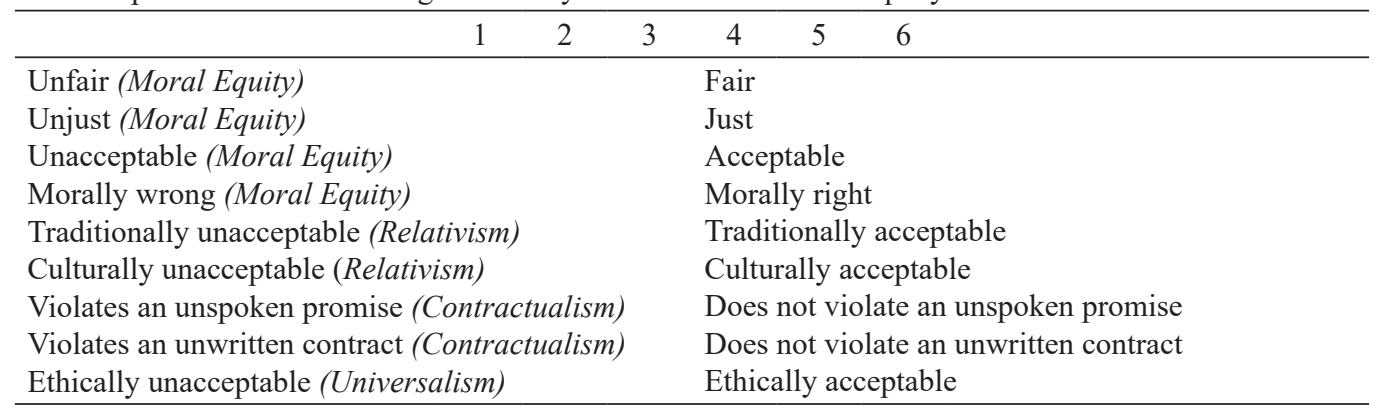

